\title{
Policies funnelling irregular migrants: On dispersed control in the emerging landscape of order production
}

\author{
By Nicolay Borchgrevink Johansen, førsteamanuensis, \\ OsloMet, Norway
}

\begin{abstract}
Norwegian
Denne artikkelen presenterer noen bestemte utviklingstrekk når det gjelder kontrollpolitikk, både i Norge og andre land det er vanlig a sammenligne med. Jeg har kalt det jeg finner for «traktpolitikk». Traktpolitikk innebcerer å inndra bidrag fra forskjellige og $i$ utgangspunktet uavhengige aktører, organisasjoner og institusjoner fra hele det politisk-administrative feltet. Bidragene blir tatt imot og viderefort $i$ den grad de passer inn $i$ det politiske feltet fra for og bidrar til det overordnede målet på feltet. Påstanden er at traktpolitikk og dens rasjonalitet gjennomsyrer den politiske og administrative håndteringen av flere marginale grupper. Formålet med artikkelen er følgelig å redegjøre for hvordan denne politikken fungerer, om enn i skisseform. Artikkelen tar for seg den mer spesifikke kontrollen med irregulore migranter som eksempel, og kan følgelig også leses som en studie av dette feltet.
\end{abstract}

\begin{abstract}
English
This article presents certain specific developments in control policy that have occurred in Norway and the countries it is commonly compared with. I have coined the term "funnelling policy" to describe what I have found. Funnelling policy involves the deduction of contributions from different and basically independent actors, organizations and institutions from the entire political-administrative field. The contributions are received and continued to the extent that they fit into the political field from before and contribute to the overall goal of the field. The claim is that funnelling policy and its rationality permeate the political and administrative handling of several marginalized groups. The purpose of the article is to explain how this policy functions, albeit in the form of a sketch. The article addresses the more specific control of irregular migrants as an example, and can therefore also be read as a study of this field.
\end{abstract}




\section{Funnel politics}

The aim of this article is to direct attention to some traits of contemporary order production that have hitherto been seen as peripheral to political developments and to show that they are important elements in the developing landscape of crime control. I want to highlight some aspects of contemporary political developments that I term funnel politics.

A funnel is used in the kitchen for pouring fluids into narrow openings. The term 'funnel politics' directs attention at how targeted individuals are isolated in a situation in which they are led to choose the desired outcome.

The concept of 'funnel politics' is based on the common observation that some unruly groups are made to suffer by various activities performed by numerous independent institutions Such observations are prevalent but have not been properly analysed. Diagnoses of contemporary crime control centre on punishment and penal laws. Explanations are sought for variations in punishment and prison numbers. Answers are found in the dynamics of neoliberalism, control cultures, penal populism and the turn toward risk assessment in the penal sphere (Garland 2001, Wacquant 2009, Feeley and Simon 1994). It is less usual to look at crime control from the broader perspective of policy developments, but Zedner and Ashworth (2013) broaden their view to include all kinds of pressures that are activated to make people conform to certain norms. The notion of funnel politics is one way of looking at a broader set of pressures in combination, in the spirit of Zedner and Ashworth.

If we take as a starting point the idea that some groups are the target of political and administrative efforts to weaken their position as members of the community, a pattern can be found that produces a quite different picture of crime control. A rationality emerges, in which political measures are not seen independently, but as contributions to the life conditions marked out for targeted groups. By reducing their quality of life, people are encouraged to choose between enduring difficulties, seeking better conditions elsewhere or adopting a different lifestyle. The rationality of funnel politics is to create a situation that can be described as follows:

\section{Current conditions $<$ alternative conditions}

Current conditions need to be worse that the alternatives. By manipulating the quality of life of the targeted groups, indirect pressure is put on them to choose the alternatives, which is the desired outcome from a policy point of view $(\mathrm{X}<\mathrm{Y})$. 
The alternatives are seen as 'order' (a politically desired situation, such as a drug free society or the absence of illegal foreigners in the country).

Funnel politics consists of separate decisions made by independent organizations and institutions. When these decisions can been seen as connected by a rationality as mentioned above, they contribute to funnel politics. Thus funnel politics must be distinguished from the individual policies made to contribute to the desired end. One important result of this construction is that the individual efforts need not be part of a general plan or in any way connected. The dispersed organizations may merely share an understanding that all contribute to the common goal.

What is understood as order depends on the policy field in question. Just as the aim of penal policy is to prevent crimes, that of drug policies is to make drug users abstain from drug use. Irregular migrants and visiting Roma are generally unwanted in Norway. Irregular migrants create disorder in at least two ways. First they are not allowed to stay on Norwegian territory and being present is in itself disorderly. Secondly, their presence creates a political crisis, since it shows that the state is unable to maintain its borders (Johansen 2018a).

The idea of creating conditions worse than the alternative, situation that is desired by the authorities is at the core of funnel politics. I will show how such policies follow a rationale which is rarely stated, and $t$ which develops by a process of trial and error. I will use policy developments regarding irregular migrants as my example throughout this article, but this puts a limit on the level of analysis that can be presented. I have formerly conducted analyses of funnel policies relating to drug use and visiting Roma (Johansen 2013, 2014a, 2014b, 2014c, 2014d, 2015, 2018a, 2018b, 2018c, 2018d), but the real topic is the emergence of certain political developments that transcend the particularities of individual fields.

\section{Irregular migrants in criminology}

Stumpf (2006) inaugurated what has later become known as the crimmigration tradition of criminology. Immigration policies have not traditionally been a topic for criminology. Even the long tradition of control studies did not examine the state's twin occupation for crime control, border control. Control studies, however, did discover that crime control was interwoven with civil society and the private sector (Cohen, 1985). In the parallel world of border control, authors had witnessed a similar development (Lahav 1998). Thus both criminology and control studies were getting to grips with the same trends. Stumpf's work overcame the 'border blindness' of criminology (Walters 2011) and brought attention to the fact that the twin activities of crime control and border control were indeed star- 
ting to overlap. Crime control was what immigration law aimed at, and border control was partly sought by means of criminal law (Stumpf 2006).

Since 2006 Stumpf's perspective has been developed, under the heading 'Crimmigration law' (e.g. Bosworth and Aas 2013, Guia, van der Woude and van der Leun 2013), which has also brought together the insights of Lahav and Cohen concerning landscapes of control. Criminology has followed this lead with a range of studies at the intersection of formerly distinct disciplines (Bosworth 2014, Amenta 2017 and Campesi 2015, to name just a few).

The concept of funnel politics was developed in research project titled 'Insiders outside/outsiders inside' ('IOOI') inspired by a phrase in by Stumpf's text. The project sought to cast light on the significance of citizenship for control policies on marginal groups. Irregular migrants were contrasted with street level drug users, who were mostly Norwegian citizens (Johansen 2018c). After some initial difficulties, this research was partly conducted in reception centres for asylum seekers.

In 2005, the surveillance theorist David Lyon said 'the border is everywhere', (Lyon 2005). Efforts to uphold territorial boundaries with respect to people and things can be made anywhere. Border control can be conducted outside the country in question (Weber and Pickering 2014) but also anywhere inside its borders. This being so, reception centres became a focal point for crimmigration studies. Reception centres are a gate into Norway and have become part of the border in two ways. First, the reception centre serves as an 'anteroom' (Berge 2011, Valenta and Berg 2011) where asylum seekers are prepared for a new life. Second, it prepares those who are going to be rejected to accept rejection. The contemporary emphasis on reducing the number of refugees seeking asylum has shifted the balance of these functions in favour of the latter. In this article, reception centres will play an important role as a focus for my own research on borders. These centres are institutions with 'mixed motives' (Leerkens and Broeders 2010): they are set up to fulfil different, and to some extent, contradictory ambitions (more on this below). So then, the border is everywhere, not least in reception centres for asylum seekers, and these sites are involved with order production. Reception centres may, therefore, be used as sites for research on emerging political trends and their combination of mixed motives illuminates the blurred and messy character of funnel policies.

The research project came to an end before the great refugee crisis had reached its climax. Accordingly, it related to the situation predating that crisis. It is fair to say that the refugee crisis disrupted the public discourse and made it a battleground for symbolically laden and heated (Sparks and Loader 2011) ex- 
changes. I will not say anything about the political messiness that ensued, but concentrate on the politico-administrative situation in 2014 and 2015.

\section{Cornerstones in controlling irregular migrants}

In the following pages I will describe funnel politics in terms of the developments that took place in regard to irregular migrants. The presentation will to some extent rely on the research mentioned above (IOOI), which centred on irregular migrants. The term 'irregular migrants' covered those committing several types of border transgressions, but mainly denoted rejected asylum seekers (Guild 2004). Departing from traditional studies of control, which tend to focus on repressive measures such as punishment, deportation, incarceration, and exclusion, I took a broader perspective, exploring how irregular migrants are manipulated by a wider set of social institutions (Johansen, 2014, 2015; see also Zedner and Ashworth 2013). Control of migrants is seen as an administrative practice. The research aimed to identify and analyse the legal framework and institutions influencing the lives of irregular migrants: Social welfare regulations, health care, authorities controlling work relations, beverage authorities, tax authorities, immigration authorities and the police constitute the main elements of the framework. Most emphasis, however, was put on institutions involved in the field of immigration policy.

Most examinations of the control of irregular migrants consider deportation. However, despite the drama of deportations when they occur, they are not an effective means to make targets leave (Valenta 2012). The secondary strategy I have pointed to, which is clearly visible and often commented on in passing, is still rarely analysed in detail: this is the production of misery. The combined effect of a wide array of measures produces life conditions for irregular migrants that make many of them suffer, though no one knows exactly how much (Johansen 2013, 2014).

Misery among irregular migrants is hard to detect, unless one has a trained eye. Despite their numbers - there are estimated to be between 20,000 and 50,000 irregular migrants (Mohn et al. 2014) - they tend to avoid attention. They seek individual ways to support themselves (Øien and Sønsterudbråten 2010, Amelie 2011) that are not visible in media coverage or statistics. The best source may well be reports from the health clinics established for this group. In their annual reports these clinics describe all kinds of ills familiar to the severely poverty stricken: malnourishment, non-specific pains, poor dental conditions, depression and other kinds of mental ill health. And this information is accessible to us only because NGOs (the Red Cross and the Church City Mission) have set and the cli- 
nics up, financing them using the surplus from other parts of their activities. The state neither offers health care nor supports it financially, but allows it to be given by others (Johansen 2013). Severely limited health care for irregular migrants is but one of many limitations on assistance. For a short time, it was also forbidden to assist irregular migrants in any way, but this regulation was quickly withdrawn (Søvig 2013). ${ }^{1}$ From 2005 there were effectively no benefits available from the social services. Recognized work is out of the question without a work permit and a 'tax license'. A tax licence is given authorized by the tax authoritites and is needed to pay taxes and to acheive formally accepted employment. The denial of welfare, work and medical care constitute the cornerstones of funnel politics regarding irregular migrants. Each of these deprivations is seen as reasonable, and they are rarely, if ever, considered in their totality. The actions taken are not assessed in terms of the total pressure exerted on irregular migrants, but judged on whether, individually, they are justifiable. Taken together, and supplemented by many smaller measures (including the conditions at reception centres), they amount to a complete denial of access to support. If no way out is found, this leads to destitution and the underlying assumption is that this condition will make irregular migrants want to leave the country of their own volition. Although rarely expressed in so many words, it is reasonable to see the measures as contributing, one by one, to the aim of preventing immigration. There is no discussion of how much misery we, as a political community, consider 'too much' destitution for the target group.

By contrast, government-approved organizations are ready to assist those who want to leave. Furthermore, some irregular migrants are eligible for financial support if they actually do leave.

Present conditions are made as terrible as is politically possible, to make leaving the country more attractive.

\section{The sum of many pieces}

When the project IOOI was planned, reception centres were closed to irregular migrants. Instead, authorities opened two camps designed as housing facilities for this group: they were called 'waiting camps'. Unfortunately for the research project, the residents of these camps torched them and they burned to the ground, never to be re-built (Kjellberg and Rugeldal 2011). Eventually the authorities re-

1. Some people assisting asylum seekers in Finnmark during winter 2015 were punished for this, but the fines were later cancelled. 
opened reception centres to irregular migrants and the research project was redirected there (Johansen 2018c). The research project therefore became tangled up with the development of the policies directed at the main target group. These developments illuminate the concept of funnel politics.

\section{Reception centres at the crossroads}

The immigration policy of the modern era was moulded in 1988. Reception centres then were set up to shelter newly arrived asylum seekers while their applications were considered by the immigration authorities. In addition, they were designed to promote integration, and prepare residents for life in their new surroundings. Of course, not all applicants were accepted, and institutions imposed restraints on their users, requiring residents to comply with certain norms. These restraints were established to make the residents integrate into Norway. Modern-day immigration policies have, therefore, always operated with a tension between integration and control (Brochman 1999). Integration predominated in the beginning, but arguably, since 2005 control has been more important. Let us start with the situation when IOOI ended, in 2015.

By the summer of 2015 approximately one third of all residents in reception centres were rejected asylum seekers. Their presence was numerically significant and, according to official statements, their numbers impacted the design of reception centres. The overarching theme in public debate, statements from authorities and policy changes was the issue of how irregular migrants could be made to leave and how asylum seekers who were going to be rejected could be prevented from coming in the first place. It is a telling fact that the immigration authorities chose 'return' as the title for their well-attended and high-profile annual conferences in both 2014 and 2015. Returning rejected asylum seekers had become the prime aim of the immigration authorities.

\section{Elements of general prevention}

A novelty in the 2008 Immigration Act was its emphasis on 'immigration political ends' as a factor in rule formation (although this is not emphasized in Vevstad $2010, \S 1)$. The resulting law combines integrative and controlling aims that are, to a certain extent, contradictory (Brochmann 2010). In addition, political ends come into conflict with the rights also granted in the same law (Vevstad 2010, $\S 45)$. Political ends meant that governing bodies were entitled to consider the implications for future immigration in their administrative decisions. The new approach had a considerable impact both on decision making in the Norwegian directorate for Immigration (UDI and UNE) and on the organization of reception 
centres. In 2011, policies on the role of reception centres were discussed extensively in a White Paper with the title 'In the anteroom of the welfare state' (Berge 2011). The title most likely reflects a change of perspective from the early days of modern-day immigration policies. Whereas the conditions making people flee their home countries used to take centre stage, in the 2011 report the committee that compiled it were focussing on Norway as a receiving country. The title thus reflected the new element introduced in the Immigration Act of 2008. The political debate centred on the contention that its high standard of living and the fact that it was a comparatively generous welfare state made Norway a particularly attractive destination for refugees (Brochmann 2010). Welfare was considered a pull-factor.

It should be noted at this point that the introduction of 'immigration policy aims' implied that local conditions and Norway's approach to handling asylum seekers, together with the country's image, were seen as elements to be manipulated to prevent future applicants from deciding to make Norway their destination. ${ }^{2}$ This is, as we shall see in more detail, funnel policies on a larger scale.

The dilemma is but one instance of the opposing interests existing from the start in modern-day reception centres. They are supposed to combine the processes of integrating inmates and of returning them to their country of origin. The focus on return activities manifests the dominance of one of these two functions, but the fact that it is a dilemma is clearly stated in the White Paper mentioned above. 'Frugal but justifiable' ${ }^{3}$ has from the start been an expression summing up this dilemma (Berge 2011). (In addition, reception centres are expected to be cost-effective.)

According to the White Paper there are no indications of a change in the balance of frugality and justifiability in annual directions from governing bodies (Berge 2011: 41). On the ground however, the emphasis in reception centres on returning inmates was evident. A detailed description of the daily routines in reception centres is not possible within this article, but three main cornerstones will be mentioned. First of all, the material standards of reception centres are usually sub-standard. The practical outcome of the principle of frugality seems to be a very poor standard of housing (Brekke and Vevstad 2007, Hauge, Denizou and Støa 2015). Secondly, during my research new positions for preparing residents for re-

2. What is also interesting here, is that this change in policy manifested the principle of general prevention in immigration politics.

3. Translated from 'nøkternt men forsvarlig'. 
turn were paid for by the UDI, sidestepping the normal sources of funding for reception centres (which indicates the importance of the project). But more importantly, the UDI included a new requirement for new contractors running reception centres: they must make sure staff are trained in the therapeutic technique of 'Motivational Interviewing' (MI) (Miller and Rollnick 2013). MI is a method of transforming everyday conversations into experiences preparing the subject for a specific purpose (Karlsen and Villadsen 2008).

The significance of this becomes clearer when considered in the light of the way reception centres are organized and funded. Immigration authorities invite tenders for running them, specifying a detailed set of requirements. NGOs, corporations and local municipalities submit bids. As of 2015, most reception centres are run by private companies which use former barracks, dormitories, hotels, schools and other types of institutions as accommodation. Reception centres are thus independent of the state and are merely bound by contractual obligations. One consequence of this arrangement is that staff are not identified as servants of the state or as responsible for decisions made by the UDI. They are, however, expected to relate to residents, both asylum seekers and irregular migrants alike, with a certain mindset.

At the reception centre in which I spent most time, all the staff were trained in MI. Thus, the authorities expected even residents' encounters with the janitor to be slanted towards the idea of returning to their country of origin, though they are not made aware of this. In this way, everyday encounters are transformed into instrumental conversations in the interests of border control.

The use of MI fits in with a well-known characteristic of reception centres: that the residents have too much time on their hands. Time passes slowly, as they wait for the next step in their asylum process. Days are often devoid of meaningful activities and it is commonly observed that residents fall in to a passive state (Mogos 2014, Valenta and Berg 2010, Vitus 2011). They are poor, deprived of daily activities and withdraw into their own world. Thus the use of MI taps into a fertile ground of emptiness. Emptiness and manipulative conversations combine to push them towards return.

To argue that reception centres have been changed from being places fostering integration to being aids to border control is probably unjustified, as they are both and it would be difficult to assess the weight of the two roles. But it should be clear from the above that reception centres have become more intertwined with border control and that border control has become an important element in their set-up. The way reception centres are associated with border control shows how policy has developed in this area. 
There is no master plan. There is a goal, to prevent immigration, and many measures are tried out to achieve this goal. No single strategy seems to have been chosen; rather we find many small efforts coming from different policy areas. The conditions in reception centres are just one part of the policy developed to pursue political ends regarding immigration. Furthermore, the design of reception centres consists of different elements not commonly seen in combination, as in the case of frugality, low level of activities, and skills in social work (MI).

These are typical aspects of funnel policies. What we find is a set of initiatives that may contribute to the desired goal. Historically they are the result of trial and error: new schemes, withdrawal of initiatives, altered initiatives, and yet more new attempts. Every suggestion is listened to, no matter how big or small. The prospect of some impact is welcomed, but whether an idea is continued with depends on how it fits in. This approach was paraded by the deputy minster at the annual conference in 2014, mentioned earlier.

\section{No stone left unturned}

The UDI invites to its annual 'spring conference' people in charge of reception centres from all over the country, as well as other partners (relevant units within the police, migration organizations etc.). Several hundred participants gather in one of the largest conference centres in Oslo. They hear lectures in a technologically advanced 'show' and during breaks mingle over coffee and a gourmet lunch. In 2014, the topic was 'return'; as it had been the year before.

The programme started with the leader of the UDI giving a speech on asylum policies and expressing gratitude for their successful cooperation in the previous year. Next on stage was the deputy minister. He said that there were huge challenges ahead and emphasized that one third of residents were not asylum seekers, legally speaking, as they had had their application rejected. They 'should have' left, and they were a burden on the reception system. He mentioned measures being employed by the political leadership to relieve this situation: more deportations and fast track handling of so-called ill-founded complaints. In addition, they had changed the words they used. Irregulars were no longer encouraged to return to their home country 'voluntarily'. This word might give some irregulars the idea that returning was up to them. And by ending the use of this phrase, they signalled that this was not the case. The message from then on was to be unambiguous: 'they had to leave'.

The speech covered several types of pushes. Greater use of deportation is what gets most political attention. However, what many observers were most struck by is the importance the deputy minister, at the suggestion of his advisors, attached 
to the words used by public servants and others representing the authorities, including the notionally independent employees at reception centres. It is hard to imagine that people who have travelled long distances, left their former lives behind, suffered exploitation of various kinds and perhaps risked death in the process, would be persuaded to return by a manipulative form of talk. However, this part of the speech makes sense if it is seen, not in isolation, but as part of a greater totality, full of similar pushes. The fact that choice of words was part of a greater picture became clearer in the finale of the speech.

'Many of the challenges seem insurmountable', the deputy minister told the audience. They were the ones administering the immigration policies and the ones that knew where the problems and possibilities were. 'You are the ones who know where the shoe pinches', he said. He then he asked them to be creative and to contact government officials directly, if they had any ideas. ${ }^{4}$

The point I want to underline is that the deputy minister invited the audience, comprised of street-level bureaucrats in the immigration sector, to contact him and his staff, with any suggestions they had. The political leadership was on the lookout for more ways to pursue their goal, and they were open to anything. This indicates that the political leadership is desperate for big and small ways of achieving their overarching aim. This is funnel politics.

\section{The emergence of funnel politics regarding irregular migrants}

Funnel politics is further illustrated when we look at developments regarding irregular migrants in more detail. The waiting camps were, as mentioned, just one phase in the development of policy on irregular migrants. Until 2005, rejected asylum seekers were offered accommodation in reception centres and received allowances for food and medicine. The so-called 'cut-back arrangement' withdrew this support. From then on, irregular migrants were deprived of most welfare benefits. There were no allowances from the UDI any more, and supposedly no benefits from the welfare sector (this point being somewhat contested). From the state's point of view, irregular immigrants were left to fend for themselves. The cut-back arrangement was a turning point in migration policy.

Destitution among irregular migrants was reported in the press, and after a while the situation became politically untenable. As a result, the two waiting camps were built, with a combined capacity of 250 places. Waiting camps were like reception centres in most ways, but with important differences. They were

4. Deputy minister Gulati, speech at the spring conference 15.05.2014. 
sited in wooded areas, with limited communications. There were high fences and residents' comings and goings were registered automatically. Food was prepared by the staff, and allowances were minimal (12 euros a week). Residents had limited access to computers and the internet, and few other leisure activities. Thus, what was offered to people without any legal means of subsistence isolated them from other networks, and gave them no meaningful activities, but supplied them with food, shelter and clothing. The waiting camps featured a number of intentional deprivations that determined the kind of life its occupants were condemned to.

However, this particular type of institution was a failure: for most irregular immigrants, it was not an acceptable alternative to the 'abandoned' life in which no food or shelter was supplied. The waiting camps were, according to reports, mostly used by people who were ill or who had disabilities (Valenta, Kjærre et al. 2010, Kjellberg and Rugeldal, 2011).

Waiting camps encapsulated the rationale of funnel politics. The fact that the camps were far away from cities resulted in their residents becoming isolated from the networks and opportunity structures available in places where there are greater concentrations of people. The allowances were so small that one week's allowance was not enough to buy a return bus ticket. The internal life of the camps was, deliberately, designed to make time spent there void of meaning. There were no activities, not even making one's own food. Leisure activities were limited. Further pressure came from the staff, who were encouraged to engage the residents in conversation and use MI (Folkeson 2009). In addition, the immigration authorities established a package of benefits for those who returned voluntarily (Valenta and Thorshaug 2011).

Following the fires at the waiting camps, a government committee made a general evaluation of reception centres (Berge 2011). The committee also discussed whether special institutions for irregulars should be set up. The idea was that they would be designed to give residents more active preparation for return (they were called 'return centres'). However, they concluded that such centres would not be effective (Berge 2011). Instead it was suggested that more emphasis should be put on support (for return) and that the experiments with conversational measures should be continued (Haarberg, Songstad et al. 2014). Return efforts were considered important, but a special institutional set-up was not expedient. As a result, irregular immigrants were allowed back into reception centres. From then on, ir- 
regular migrants would get lower allowances, ${ }^{5}$ and they would meet staff trained in MI.

Although they start at an earlier point in their descriptions of policy initiatives, Haarberg et al. (2014) set 'return work', with its emphasis on 'voluntary return', in the same historical context as I did. These authors identify the beginning of the trajectory as back in 2002 when a government programme was established to assist rejected asylum seekers who wanted to return. The waiting camps were the next step, according to these authors, (who thus ignored the cut-back arrangement). Their historical account also included experiments with withdrawal of Norwegian language training and user participation in reception centres. The authors also considered waiting camps in the context of the development of communicative means involving emphasis on information and conversation techniques (Haarberg, Songstad et al., 2014). Although Haarberg et al. and I emphasize different elements, we both see a trajectory in which there is an emphasis on apparently small and innocuous elements from different policy spheres.

Again, the recurring perception that emerges from my own research (Johansen $2018 \mathrm{c}$, Johansen forthcoming) and from that of the commentators mentioned above, is that policy is developed by trial and error, and yet more trial, to bring to bear various forms of pressure that might all push in the same direction.

All the measures activated in pursuit of the desired goal contribute to a totality. But this totality is not necessarily subject to separate deliberations. The situation is unwanted, and every measure available is brought in, if it fits with the other initiatives and the political climate. ${ }^{6}$

\section{Funnelling irregular migrants}

There are many more attributes of funnel politics that could and perhaps should be discussed. I will end this presentation with some brief remarks on some of them.

The argument does not rest on a presumption that the strategies mentioned are results of conscious plans. Rather, it seems clear from the examples cited that the

5. Allowances for asylum seekers are meticulously calculated on the basis of estimated costs and compared to social welfare benefits. They include a small portion of 'pocket money'. Irregular migrants had their pocket money taken away, which resulted in a $33 \%$ reduction of their spending power (Berge 2011).

6. The cut back clause was withdrawn when the destitution of irregulars became a public issue. The effect of policies regarding irregular migrants is still a heavy burden on them. 
strategies have developed bit by bit and were rarely anyone's first choice, or the primary solution adopted within the different spheres. It is more a case of government organizations picking items from the available toolbox (Garland 1985).

If regarded as funnel policies, many aspects of control used with marginal groups, that otherwise might appear peripheral, become comprehensible and can be seen as central to the outcome of the policies. My intention has been to show that there are policy developments regarding marginal groups that do not fit into the framework of penal law and traditional penal policy. ${ }^{7}$

If the cornerstones outlined above help create tight walls, the targets will have no other option than to seek opportunities in the opening in the bottom of the funnel. But, unlike real funnels made of plastic or steel, funnel politics is made up of permeable stuff. It is almost impossible to create a social fabric without holes or to isolate people in situations devoid of opportunities to find illegal or informal resources.

These considerations open the way for an analytical distinction within the sphere of funnel policy; between setting up cornerstones and the creation of the big picture on the one hand, and the maintenance of the established structure on the other.

\section{Maintenance of the big structure}

Maintenance can often be seen going on at the level of administration. Administrative organizations are drawn in to repair loopholes in a structure. One example of this is provided by an incident that occurred in 2010. By chance, the Tax Authorities came across approximately 100 irregular migrants of Ethiopian origin who were receiving tax licences automatically. They had been legitimate recipients of tax licences when they were asylum seekers, but when their applications had been rejected, they were no longer permitted to work. Some of them had discovered that it was possible to ask for a renewal of the tax licence, and that renewals were granted without checking changes in the applicant's legal status according to the people's registry (actually administered by the same tax authorities). Losing tax license was devastating for the people involved and there was a political outcry. The Ethiopians started a campaign to reverse the decision (Dagne 2015). But the campaign could not be successful: there was no political decision

7. It is my contention that a broader view of penal history, that includes the welfare state (Garland 1985/2018), allows for a better understanding of the emergence of dispersed order production (Johansen 2014). 
to reverse. The legal foundations were already in place and were not publicly contested in political circles. The result demonstrated how effective administration upheld a political decision, or to put it differently, the tax authorities maintained the structure for making irregular migrants leave.

The example points to the importance of implementations of politics and of effective administration. Public servants may not be aware of holes in the structure, may not make irregular migrants a priority or may more consciously look the other way out of sympathy or compassion. Poor administration and monitoring of different political areas, such as tax licences, create loopholes for the target group. At some stage, a rejected asylum seeker, probably of Ethiopian descent, discovered that it was possible to continue having tax licenses. And after that, the information circulated within a closed network until it was discovered. They were looking for loopholes, keeping their eyes open for opportunities to make a living in any way. It would be possible to study the interface between public servants and irregular migrants as a cat-and-mouse game. Van der Leun did this in a study of irregular migrants in Rotterdam, in the Netherlands, against the background of the so-called Linking Act that was passed in 1998. This law was similar to the cut-back arrangement that disconnected rights and status. The Linking Act deprived irregular migrants of rights to welfare benefits and housing.

Van der Leun set out to analyze how immigrants adapt to the 'discouraging' policies adopted by the Dutch authorities in the late 1990s. She does so partly by investigating control mechanisms in action, and manages to create a picture of the control structure erected in the Netherlands in the first years of the new century.

The book bears the title 'Looking for loopholes', which describes the approach of irregular migrants in her study. The first loophole is within the formal economy. She mentions several sectors (restaurants and horticulture among others) which are known to hire irregular migrants. The second loophole is the black economy: the drug trade, prostitution and, to some extent, theft. So far, there are no surprises. However, she produces some not-so obvious findings regarding how employers and employees, in the first instance, cooperate to circumvent the rules. Her take on the third loophole follows a similarly not-so-obvious course. Van der Leun found that street-level bureaucrats tasked with upholding the Linking Act had several ways of getting round these regulations: A) There were rules defining situations where the restrictions did not apply; B) Deportations were hard to carry out; C) Police officers, social workers and others used their wide scope of discretion to the advantage of irregular migrants. Police officers did not consider these tasks important (enough) and social workers sympathized with their clients. The 
regulations thus provided opportunities, and the scope for discretion left room to bypass the political aims set out in the Linking Act.

Funnel policies include at least two distinct elements. The first is the aim to erect a framework that isolates targeted groups in a position of deprivation that can also be manipulated by political means. The second element is constant work to repair cracks in the structure. The targeted groups will look for loopholes, and the maintenance of funnel policies involves efforts to shut down alternative ways of surviving.

\section{A Broader view}

Funnel policies are not a Norwegian or Nordic phenomenon. Van der Leun's work is one of very few studies that describe the dynamics I call funnel policies, although the author does not herself use this term. The reality she describes is in the Netherlands. There are also some UK studies that may support my perspectiveindirectly (e.g. Hynes 2011, Shukla 2017, Jones et al. 2018). The absence of a framework transcending the penal realm seems to be a block to understanding how policies evolve in these areas, and my suggestion is funnel politics. Recent developments in Great Britain have made the issue topical. In the spring of 2018 the Windrush scandal caused the Home Secretary to resign. It came to light that immigrants from the Caribbean were being systematically deprived of their rights as citizens. These deprivations, from all kinds of welfare benefits, including health care, housing and social support, were the result of what seemed minor administrative actions no-one foresaw the effect of at the time of execution. To put it briefly, immigrants from the 50s and 60s lost their rights as citizens when they failed to apply for a passport within a certain time limit. The most interesting point for our purposes is that these decisions were interwoven with a vaguely expressed political strategy. This strategy was given a name by the former Home Secretary, the current Prime Minster Theresa May, in an interview with a newspaper in 2011. She called it a 'hostile environment' (Johansen 2018b). This is what funnel policies is about, making life conditions sufficiently bad to provoke the target group to choose to leave for somewhere else.

In the summer of 2018 a group of academics and activists were called upon to discuss the emerging political landscape (No Walls 2018), but I argue they would have benefitted from looking at the Windrush saga as an instance of funnel policy. 
Nicolay Borchgrevink Johansen - Policies funnelling irregular migrants: ...

\section{References}

Amelie, M. (2010). Ulovlig norsk. Oslo, Pax.

Armenta, A. (2017). Protect, Serve, and Deport: The Rise of Policing as Immigration Enforcement. University of California Press.

Berge, G. (2011). I velferdsstatens venterom: mottakstilbudet for asylsøkere: utredning fra utvalg oppnevnt ved kongelig resolusjon 27. oktober 2009: avgitt til Justis- og politidepartementet 6. juni 2011. Oslo: Departementenes servicesenter, Informasjonsforvaltning.

Bosworth, M. and K.F. Aas, (eds) (2014). Borders of Punishment. Oxford: Oxford University Press.

Bosworth, M. (2014). Inside Immigration Detention. Oxford: Oxford University Press.

Brekke, J.-P. and S. Søholt (2005). I velferdsstatens grenseland: en evaluering av ordningen med bortfall av botilbud i mottak for personer med endelig avslag på asylsøknaden. Oslo, Institutt for samfunnsforskning.

Brekke, J.-P. and V. Vevstad (2007). Reception conditions for asylum seekers in Norway and the EU. Oslo, Institutt for samfunnsforskning.

Brochman, G (1999). Mechanisms of Immigration Control. A Comparative Analysis of European Regulations Policies. Oxford: Berg.

Brochmann, G. (2010). Innledning. Innvandringskontroll i en internasjonalisert velferdsstat. In Vevstad, V. (ed. 2010). Utlendingsloven. Oslo: Universitetsforlaget.

Campesi,G (2015). Hindering the deportation machine: An ethnography of power and resistance in immigration detention. Punishment \& Society 17(4), pp. 427-453.

Cohen, S (1985). Visions of Social Control. Polity Press.

Dagne, W (2015). Give Us a Damn Paper! Cases of Anti-Deportation Campaigns by Rejected Ethiopian and Palestinian Asylum Seekers in Norway. Master's thesis, University of Oslo, Norway.

Djuve, A.B., J.H. Friberg, G. Tyldum and H. Zhang (2015). When poverty meets affluence. Fafo report. Oslo, FAFO. https://www.fafo.no/images/pub/2015/954-innmat-trykk.pdf.

Feeley, M. and J. Simon (1994). Actuarial Justice: the Emerging New Criminal Law. In The Futures of Criminology. D. Nelken. London: Sage, pp. 173-201.

Folkeson, S. (2009). Ingenmannsland: en rettssosiologisk studie av avviste asylsøkeres rettslige og sosiale situasjon, med fokus på ventemottaket som returfremmende tiltak. Master's thesis, University of Oslo, Department of criminology and sociology of law.

Garland, D. (1985). Punishment and welfare: A history of penal strategies. Aldershot, UK: Ashgate.

Garland, D. (2001). The culture of control: Crime and social order in contemporary society. Chicago, IL: University of Chicago Press.

Guia, van der Woude and Van der Leun (2013). Social Control and Justice: Crimmigration in the age of fear. The Hague: Eleven International Publishing,pp. 41-60.

Guild, E. (2004). Who is an Irregular Migrant? In Irregular migration and human rights. B. Bogusz, R. Cholewinski, A. Cygan and E. Szyszcak (eds). Leiden: Martinus Nijhoff.

Haarberg, K., S.O. Songstad, et al. (2014). Evaluering av returtiltak i ordincere mottak. Oslo: Deloitte.

Hauge, Å.L., K. Denizou and E. Støa (2015) Bokvalitet på norske asylmottak. Trondheim: Sintef akademisk forlag. 
Hynes, P. (2011). The dispersal and social exclusion of asylum seekers: between liminality and belonging. Bristol: Policy Press.

Johansen, N.B. (unpublished paper). Governing Borders: Soft Power and Hard Realities in Reception Centres.

Johansen, N.B. (2013). Elendighetstrakten. In Johansen, Ugelvik and Aas (eds) Krimmigrasjon? Oslo: Universitetsforlaget.

Johansen, N.B. (2014a). Governing the funnel of expulsion. In The Borders of Punishment: Migration, Citizenship, and Social Exclusion. Oxford University Press.

Johansen, N.B. (2014b). Det strafferettslige kompleks. Strafferetten og biopolitikkens nye grenser anno 1902. In Straff, Liv, Historie, Flaatten S and G Heivoll (eds). Oslo: Akademisk publisering.

Johansen, N.B. (2014c). Lik rett til å sove (equal rights to sleep). Motmoele. L. Finstad and H.M. Lomell (eds), Pax forlag, Oslo.

Johansen, N.B. (2014d). Forcing immigrants out - new constellations of penal and administrative justice. Report from the 50th research seminar, Skarrildhus, Denmark. M. Tønder. Aarhus, Scandinavian Research Council for Criminology. 50.

Johansen, N.B. (2015). Controlling Roma in Norway: governing through the administration of social distance. In Eriksson, Anna (ed.) Punishing the Other: The Social Production of immorality Revisited. Routledge.

Johansen, N.B. (2018a). Knowledge/recognition: Counting and the predicament of the permeable biopolitical state. Theoretical criminology June 2018: https://doi.org/10.1177\%2F1362 480618779402.

Johansen, N.B. (2018b). Funneling disobedient individuals: On the declining importance of penal law in order production. In Report from the 60th Research Seminar of Scandinavian Research Council for Criminology, held at Hotel Rantapuisto, 14.-16.5.2018.

Johansen, N.B. (2018c). Framing an irreal space. In Fili, A., R. Powell and S.Ø. Jahnsen (eds) Criminal Justice Research in an Era of Mass Mobility. London: Routledge.

Johansen, N.B. (2018d). Governing Marginality through Welfare. Federal Sentencing Reporter, Vol. 31, No. 1, pp. 90-98. Vera Institute of Justice, University of California Press.

Jones, H.Y. Gunaratnam, G. Battacharyya, W. Davis, S. Dhaliwal, K. Forkert, E. Jackson and R. Saltus (eds) (2018). Go Home? Manchester: Manchester University Press.

Karlsen, P.K. and K. Villadsen (2008) Who Should do the Talking? The Proliferation of Dialogue as Governmental Technology. Culture and Organization 14(4), pp. 345-363.

Kjellberg, J. and C. Rugeldal (2011). Illegal: papirløs i Norge. Oslo: Spartacus.

Lahav, G. (1998). Immigration and the State. Journal of Ethnic and Migration Studies. Vol 24 (4), pp. 675-694.

Leerkes, A. and D. Broeders (2010). A Case of Mixed Motives? British Journal of Criminology 50(2): 21 .

Lyon, D. (2005). The Border is everywhere: ID Cards, Surveillance and the Other. Global Surveillance and Policing: Borders, Security, Identity. E. Zuriek and M. Salter. Cullompton: Willan.

Miller, W.R. and S. Rollnick (2013). Motivational interviewing: helping people change. New York: Guilford.

Mogos, N.H. (2014). Mottaket. Z-forlag. 
Mohn, S., Ellingsen, D., Solheim, Ø. and Torgersen, K. (2014). Et marginalt problem? Asylsøkere, ulovlig opphold og kriminalitet. Oslo: UDI. https://www.udi.no/globalassets/global/ forskning-fou_i/beskyttelse/et-marginalt-problem---endelig.pdf

No Walls (2018). The anatomy of the the lost environment: a weekend with Birkbeck school of law. Blogpost, 30.10.2018: https://www.no-walls-dl.org/no-walls-blog/2018/10/30/theanatomy-of-the-hostile-environment-a-weekend-with-birkbeck-school-of-law

Shukla, N. (2017). The Good immigrant. London: Unbound.

Simon, Jonathan (2007). Governing Through Crime. Oxford University Press.

Søvig, KH (2013). Straffansvar og straffeforfølgning av humanitære hjelpere ved ulovlig opphold. Krimmigrasjon? N.B. Johansen, K.F. Aas and T. Ugelvik. Oslo: Universitetsforlaget.

Sparks, R and I. Loader (2011). Public Criminology. London: Routledge.

Stumpf, J. (2006). The Crimmigration Crisis. Bepress Legal Series (1635).

Valenta, M. (2012a). Avviste asylsøkere, kamp mot uttransportering og livet utenfor mottakssystemet. In Asylsøker: $i$ velferdsstatens venterom. M. Valenta and B. Berg. Oslo: Universitetsforlaget.

Valenta, M. (2012b). Hvordan kan vi analysere asylfeltet med hjelp av sosiologisk teori? In Asylsøker: $i$ velferdsstatens venterom. M. Valenta and B. Berg. Oslo: Universitetsforlaget.

Valenta, M. and B. Berg (2010). User Involvement and Empowerment among Asylum seekers in Norwegian Reception Centres. European Journal of Social Work 13(4).

Valenta, M., H.A. Kjærre, et al. (2010). Avviste asylsøkere og ventemottaksordningen: mellom passiv tvang og aktiv returassistanse. Trondheim, NTNU samfunnsforskning, Avdeling for mangfold og inkludering.

Vevstad, V. (ed. 2010). Utlendingsloven. Oslo: Universitetsforlaget.

Vitus, K. (2011). Zones of Indistinction: Family Life in Danish Asylum Centres. Distinktion: Scandinavian Journal of Social Theory 12(1).

Wacquant, L.J.D. (2009). Punishing the poor. Durham, N.C.: Duke University Press.

Walters W. (2011) Foucault and Frontiers: Notes on the Birth of the Humanitarian Border. In: Bröckling U, S Krasmann and T Lemke (eds) Governmentality: Current Issues and Future Challenges. New York: Routledge.

Zedner, L. and A. Ashworth (2014). Preventive Justice. Oxford: Oxford University Press.

Øien, C. and S. Sønsterudbråten (2011). No way in, no way out? A study of living conditions of irregular migrants in Norway. Oslo: Fafo. 